\title{
Book Review: Collective Skill Formation in Liberal Market Economies? The Politics of Training Reforms in Australia, Ireland and the United Kingdom
}

\author{
Fabienne-Agnes Baumann* \\ University of Osnabrück, Working Group on Vocational Education and Training, \\ Institute of Education, School of Educational and Cultural Studies, \\ Katharinenstr. 24, 49076 Osnabrück, Germany.
}

Published: 17.12 .2018

\section{Book Review}

Collective Skill Formation in Liberal Market Economies? The Politics of Training Reforms in Australia, Ireland and the United Kingdom, by Janis Vossiek, Peter Lang, Bern/Switzerland, 2018, 226 pp., ISBN 978-3-0343-2969-9 (paperback) about 66€, ISBN 978-3-0343-2971-2 (e-pub) about 74€, ISBN 978-3-0343-2970-5 (PDF) about 74€.

The book was published as the $16^{\text {th }}$ volume of the series Studies in Vocational and Continuing Education. Series Editors-in-Chief are Philipp Gonon and Anja Heikkinen. Janis Vossiek is a post-doctoral researcher at the School of Educational and Cultural Studies of the University of Osnabrück, Germany.

\section{Purpose}

The monography is based on the author's doctoral dissertation. An introductory chapter is followed by the outline of the theoretical framework for the study. At the heart of the volume are the three case study chapters on the United Kingdom, Ireland and Australia

\footnotetext{
*Corresponding author: fabienne.baumann@uos.de
} 
which all contain a brief summary of the country-specific findings. The latter are drawn together for a cross-country comparison in the conclusion.

The purpose of the book lies in expanding the academic discourse on collective skill formation regimes to the realm of liberal market economies, with the aim to contribute to advancing the underlying theoretical assumptions of institutional political economist research on Vocational Education and Training (VET). In addition, Vossiek's study focuses on issues evolving around institutional change in VET regimes during later stages of their evolution as compared to skill formation literature more interested in the genesis of relevant institutions. With a view to explanatory variables the book combines a concern for patterns of economic coordination as put forward by literature on Varieties of Capitalism ( $\mathrm{VoC}$ ) with one for partisan politics and therefore goes beyond the firmcentered perspective of existing VoC-research.

\section{Content}

Vossiek's book starts off with situating the contribution among research on dual apprenticeships. His take on this topic is shaped by the growing body of literature on Vocational Education and Training (henceforth VET) by scholars identifying as institutional political economists. Conceptually, the author draws on Busemeyer and Trampusch's (2012) work on collective skill formation as well as contemporary comparative capitalism research, specifically Hall and Soskice's (2001) Varieties of Capitalism (VoC) approach.

Vossiek draws attention to the fact that collective skill formation is commonly thought of as the reserve of coordinated market economies (CMEs) in which the collaboration between key political actors- vital in sustaining apprenticeships- is likely to be facilitated by relevant institutional arrangements. Due to their reliance on market-driven mechanisms and hierarchies, stakeholders in liberal market economies (LMEs) are less likely to engage in coordination. LMEs are often burdened with a history of VET being sharply contested between capital and labor and reluctance of the state to mediate, which lowers the prospects for collective governance of VET and has contributed to weakening apprenticeship provision.

By studying the skill formation regimes of Australia, Ireland and the United Kingdom, all of which are liberal market economies, Vossiek challenges this state of research and finds that LMEs, too have the propensities for VET that is rather more collective than suggested by previous findings. The author's research is driven by three central questions. The first one centers on the different traits of collective skill formation in the three LMEs, on whether reforms have led to institutional change that led to skill formation either being more or less collective afterwards. Secondly, Vossiek seeks explanations for diverging paths with regard to collective skill formation in the face of similar outsets in the three countries observed. The focus here is on coalitions between key stakeholders in VET- in the case of this book this means partisan governments and organized capital and labor- and reasons for reforms. The third question is about the implications of Vossiek's work for research on VET and institutional change.

The theoretical approach employed by the author builds on existing research by institutional political economists, the body of literature to which Vossiek aims to contribute. 
This means on the one hand building on the merits of contemporary comparative capitalism research, above all the aforementioned VoC-approach but challenging VoC's conceptualization of skills, its neglect of the historicity of institutions and its take on institutional stability and change. On the other hand, scholars of institutional political economy commonly employ a historical institutionalist lens through which explanations for similarities and differences between VET systems are developed. In Vossiek's case the main threads of the analytical framework are the following: it is assumed that crossclass coalitions are important for sustaining apprenticeship systems or for moving closer towards a collective VET regime; the expectation that partisan politics are central for the nature of policies relevant to VET and for determining the relationship between VET stakeholders and between the latter and the government; the presumed relevance of path-dependency with regard to reforms in the political arena of VET.

Data for the book has been generated by conducting several dozens of expert interviews with relevant VET-stakeholders in Australia, Ireland and the United Kingdom. In addition, the author has analyzed secondary literature on the three cases as well as primary sources. Methodologically, Vossiek has engaged in process tracing, one of the most prominent tools applied in historical institutionalist research. The analysis spans roughly forty years, starting in the 1960 s and ending in the first decade on the $21^{\text {st }}$ century.

A central finding of the book is that there are indeed marked differences within the group of liberal market economies as far as the politics of VET are concerned. Vossiek ably demonstrates that the United Kingdom has in fact moved further away from a collective skill formation regime while Australia, and Ireland even more so, have moved closer to it during the decades under study. The divergence between the three cases, despite similar conditions up until the 1960s, is explained by referring to the different governmental constellations and, consequently, the different nature of reforms implemented or attempted in the face of economic crises. While Australia and Ireland have resorted to facilitating collaboration and compromise between key political actors- particularly organized capital and labor- the United Kingdom has opted for policies much to the detriment of collectivist solutions, essentially focusing on excluding organized labor from the political arena of VET. At the same time, successive attempts to overcome more voluntary forms of firm involvement in VET have failed in the UK as reforms did not lead to changing the preferences of firms, thus institutional change did not occur. In contrast to this, the author posits that in Australia and Ireland, the implementation of policies promoting cross-class collaboration in VET was closely linked to finding consensus in the realm of industrial relations as well, thereby ensuring a broader basis for more sustainable capital-labor-coalitions. These diverging trajectories are explained by pointing to the differences between non-right-wing (Australia, Ireland) and right-wing (UK) governments concerning the skill formation agenda. A prerequisite for realizing these agendas, Vossiek finds, were economic crises that served as a backdrop and as the legitimization for pursuing the one or the other strategy.

Hence, the other key insight the book is providing is that patterns of economic coordination alone cannot sufficiently explain differences between countries regarding their approach to VET. If this were the case than the puzzle of a collectivist turn in Australia 
and Ireland until the mid-1990s would remain unsolved. Consequently, Vossiek argues and shows that political coordination matters, too.

\section{Conclusion}

The central merits of Vossiek's contribution are that firstly, it has carried collective skill formation into the realm of liberal market economies. While providing insights from these least likely cases is first and foremost geared towards theory building, looking at collective skill formation in LMEs potentially encourages scholars to endeavor further geographic expansion of research on the much discussed brand of skill formation that is the collective type, thereby leaving behind the limitations of Hall and Soskice's CMELME-dichotomy.

Secondly, by drawing attention to the importance of both, economic and political coordination the study underlines that monocausal argumentation is not viable as regards research on VET and especially the explanation of differences between training systems. Vossiek's book strengthens the argument put forward by previous authors about the co-evolution of institutions such as those of VET and industrial relations. It also falls in line with existing institutional political economist research by making a strong case against the state' as neutral broker between stakeholders in the political arena of VET (and elsewhere), instead the study sheds light on the importance of state structures and partisan politics in determining the nature of the relationship and power distribution between key political actors.

Thirdly, Vossiek underlines once again, that VET regimes are not static but rather the products of recurring contestation of their constituent institutions by political actors. Apart from these achievements, two issues should be addressed. The first regards the preferences of political actors. Vossiek's analysis builds on a central tenet of the historical institutionalist political economy of VET: that cross-class relations and whether and how they are mediated by the state (for instance in the form of industrial relations or corporatism) are a central explanatory variable for differences between VET systems.

The reader is provided with insights into how stakeholder collaboration was sanctioned or dismantled by successive governments in the three LMEs and it is illustrated how governmental programs with a view to VET have evolved over time. However, this scrutiny is lacking concerning organized capital and labor. The analysis does not delve deeper into organized capital and labor's preferences and strategies regarding VET, neither in the country-chapters nor in cross-national comparison. What (if anything) did organized capital and labor exactly have to say about VET at different moments in the history of skill formation in the three cases? (How) Did this impact on why preferences were or weren't considered in the political arena of VET?

How has the nature of skill formation institutions and how have reforms impacted on preferences and strategies? While one learns whether capital or labor's preferences changed over time, it is not clear what precisely was subject to change and which legacies weighed too heavy to be done away with. 
It is argued here that a closer look at organized capital and labor's preferences and strategies would have provided additional substance for explaining processes of institutional change (or the absence thereof). It would have also contributed to a deeper understanding of cross-class relations and the distribution of power between the state, capital and labor concerning skill formation.

The second issue concerns the relevance of assumptions or expectations about partisan politics i.e. the preferences of political parties regarding certain policy areas and their ties with or distance to specific political actors and organized interests. This is not to deny that partisan politics matter, rather future research needs to ask whether one can still build on what is attributed to different partisan camps in the face of ongoing and more recent political trends that seem to blur the lines between right and left, conservative and progressive and so forth. Moreover close attention needs to be paid to what these labels actually mean in a given national context.

Vossiek's book might come in handy for practitioners and policy makers engaged in reforming education and training systems; it is certainly of interest for all those committed to understanding and explaining historical trajectories of, as well as variations between VET systems.

\section{Biographical Note}

Fabienne-Agnes Baumann, M.Sc. / MA is a research assistant and doctoral researcher at the University of Osnabrück, Germany. Her research focus is on international and internationally comparative studies on VET in emerging and developing economies, she is particularly interested in the politics of VET. 